\title{
INFEKSI VIRUS EBOLA
}

\author{
Novie H. Rampengan
}

Bagian Ilmu Kesehatan Anak Fakultas Kedokteran Universitas Sam Ratulangi Manado

Email: novierampengan@yahoo.com

\begin{abstract}
WHO announced the outbreak of Ebola virus (EBOV) which can manifest as fever, severe diarrhea, and vomiting. In Africa, there are 3 types of Ebola viruses that cause the biggest outbreaks: EBOV, Sudan ebolavirus, and Bundibugyo ebolavirus. The transmission of these viruses to human body is via direct contact with blood, secret,organ, or other body fluid of the infected person. The onset of this transmitted disease after the incubation period is 2 to 21 days. The mortality of Ebola infection is still high in human.
\end{abstract}

Keywords: Ebola, virus, Africa outbreak

\begin{abstract}
Abstrak: WHO mengumumkan adanya outbreak dari virus Ebola (EBOV) yang ditandai dengan adanya demam, diare berat, dan muntah. Di Afrika, terdapat 3 jenis virus Ebola yang menyebabkan wabah terbesar, yaitu: EBOV, Sudan ebolavirus, dan Bundibugyo ebolavirus. Transmisi virus Ebola masuk ke dalam tubuh manusia ialah dengan kontak langsung dari darah, sekret tubuh, organ atau cairan tubuh lainnya dari orang yang terinfeksi. Onset dari penyakit ini setelah terjadi inkubasi period adalah 2 sampai 21 hari. Mortalitas dari infeksi virus Ebola masih tinggi pada manusia.
\end{abstract}

Kata kunci: Ebola, virus, wabah di Afrika

Pada bulan Maret 2014 WHO mengumumkan adanya wabah dari penyakit menular yang ditandai adanya demam, diare berat, dan muntah dengan tingkat keparahan yang tinggi di Guinea. Wabah ini disebabkan oleh virus Ebola (EBOV) dan Marburg (MARV). Virus Ebola menyebabkan tingkat keparahan mencapai 30-90\%, bergantung pada spesies virus itu sendiri. ${ }^{1}$ Wabah penyakit ini telah diidentifikasi setiap tahun selama 3 tahun terakhir di Afrika Tengah. Laporan terakhir didapatkan di Republik Congo dan menurut WHO terdapat sekitar lebih dari 125 kasus yang fatal. ${ }^{2}$

\section{EPIDEMIOLOGI}

EBOV merupakan patogen agresif yang menyebabkan gejala demam dengan perdarahan yang letal pada manusia dan hewan. Adanya penyakit ini pertama kali ditemukan di dekat sungai Ebola dengan wabah di Zaire pada tahun 1976. Outbreak sudah terjadi di Afrika selama 27 tahun dengan mortalitas berkisar antara 50-90\%. ${ }^{2}$ Penyebaran virus Ebola tidak hanya terjadi di Afrika. Jenis virus yang baru Reston ebolavirus (REBOV) ditemukan pada kerakera yang diimpor dari Manila (Filipina) ke Amerika pada tahun $1989 .^{3}$

\section{VIRUS EBOLA}

\section{Virus Ebola dan fatalitas}

Di Afrika terdapat 3 jenis virus Ebola yang menyebabkan wabah terbesar, yaitu: EBOV, Sudan ebolavirus dan Bundibugyo ebolavirus. Nilai fatalitas EBOV dapat mencapai 30-90\% tergantung pada jenis virus.

Virus Ebola berasal dari golongan Filoviridae. Jenis ini merupakan virion pleomorfik yang dapat berbentuk huruf $U$, angka 6 , atau lingkaran, tetapi yang paling 
sering terlihat di mikroskop elektron ialah struktur tubular panjang. Virus Ebola mengandung 1 molekul linear singlestranded dengan negative-sense RNA yang hampir mirip dengan Paramyxoviridae.

\section{Transmisi virus Ebola}

Transmisi virus Ebola masuk ke dalam tubuh manusia melalui kontak langsung dari darah, sekret tubuh, organ atau cairan tubuh lainnya dari individu yang terinfeksi. Di Afrika, pada upacara kremasi dari penderita yang terinfeksi virus Ebola yang kemudian terkontak dengan individu yang sehat bisa menyebabkan terjadinya penularan virus ini. Transmisi virus dari hewan ke manusia juga dapat terjadi saat manusia berkontak dengan jaringan dan cairan tubuh dari hewan yang terinfeksi. Proteksi terhadap tenaga kesehatan yang menangani penderita Ebola juga sangat penting. Walaupun virus Ebola tidak ditularkan melalui udara, penularan lewat droplet bisa terjadi di laboratorium. ${ }^{3-5}$

\section{INFEKSI VIRUS EBOLA}

\section{Patogenesis}

Efek akhir dari infeksi virus Ebola ialah syok yang disebabkan oleh beberapa proses yang memengaruhi satu sama lainnya, yaitu: replikasi virus sistemik, supresi sistem imun, peningkatan permeabilitas pembuluh darah, dan koagulopati (Gambar 1). Infeksi pada sel target utama seperti monosit/makrofag dan sel dendritik menghasilkan penyebaran sistemik dari virus dan aktivasi diferensiasi sel. Monosit/makrofag yang teraktivasi akan menghasilkan sitokin proinflamasi dan tissue factors, sedangkan aktivasi sel dendritik yang terganggu menyebabkan rendahnya perlindungan respon imun. Meskipun virus tidak menginvasi limfosit dan sel natural killer (NK), apostosis ekstensif dari sel-sel sekitarnya dapat terjadi. Sel endotelial kemudian diaktivasi oleh sitokin proinflamasi dan partikel virus yang menyebabkan permeabilitas meningkat. Tissue factors yang dihasilkan oleh monosit/makrofag menginduksi koagulopati dan juga dapat meningkatkan inflamasi. $^{5}$

\section{Gejala dan tanda klinis}

Onset penyakit ini setelah terjadi inkubasi ialah 2-21 hari. Gejala klinis dapat dibagi dalam 4 fase, yaitu: ${ }^{3}$

1. Fase A: Influenza like syndrome. Terjadi gejala atau tanda nonspesifik seperti panas tinggi, sakit kepala, artralgia, mialgia, nyeri tenggorokan, lemah badan, dan malaise.

2. Fase B: Bersifat akut (hari ke 1-6). Terjadi demam persisten yang tidak berespon terhadap obat anti malaria atau antibiotik, sakit kepala, lemah badan yang terus menerus, dan diikuti oleh diare, nyeri perut, anoreksia, dan muntah.

3. Fase C: Pseudo-remisi (hari ke 7-8). Selama periode ini penderita merasa sehat dengan konsumsi makanan yang baik. Sebagian penderita dapat sembuh dalam periode ini dan selamat dari penyakit.

4. Fase D: Terjadi agregasi (hari ke 9). Pada beberapa kasus terjadi penurunan kondisi kesehatan yang drastis diikuti oleh gangguan respirasi; dapat terjadi gangguan hemostasis berupa perdarahan pada kulit (petekia) serta gangguan neuropsikiatrik seperti delirium, koma, gangguan kardiovaskular, dan syok hipovolemik. ${ }^{3}$

\section{Diagnosis}

Diagnosis infeksi virus Ebola dapat dikonfirmasi bila dicurigai adanya demam yang diikuti perdarahan dan adanya kontak dengan hewan yang dicurigai terinfeksi virus Ebola. Diagnosis dapat ditegakkan dengan menggunakan metode PCR dan isolasi virus dengan Vero cells. Pemeriksaan laboratorium tambahan mencakup ELISA untuk mendeteksi antibodi spesifik IgG dan IgM Ebola. ${ }^{3}$ 


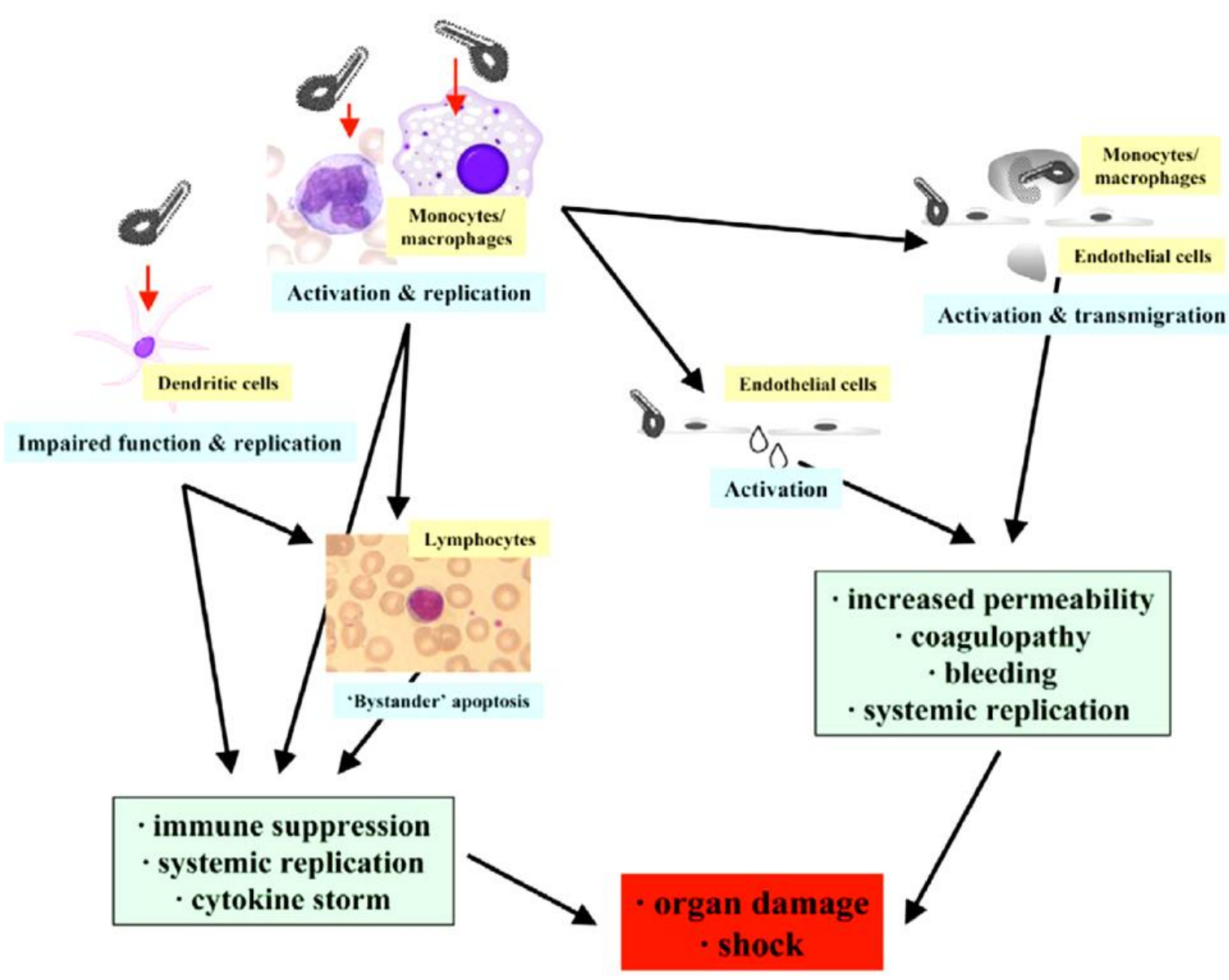

Gambar 1. Patogenesis infeksi virus Ebola. Hasil akhir infeksi virus Ebola berat ialah syok yang disebabkan oleh beberapa proses yang saling memengaruhi: replikasi virus sistemik, supresi sistem imun, peningkatan permeabilitas vaskular, dan koagulopati. Infeksi primer dari sel target seperti monosit/makrofag dan sel dendritik menghasilkan penyebaran sistemik dari virus dan aktivasi diferensiasi sel. Monosit/makrofag diaktifkan untuk memroduksi sitokin proinflamasi dan tissue factors, sedangkan sel dendritik teraktivasi yang rusak memperburuk respon imun protektif. Meskipun virus tidak menginfeksi limfosit dan sel natural killer (NK), apoptosis terjadi pada semua tipe sel. Sel endotel kemudian diaktivasi oleh sitokin proinflamasi dan partikel virus yang menyebabkan peningkatan permeabilitas. Pelepasan tissue factors dalam monosit/makrofag merangsang koagulopati, yang juga mengakibatkan peningkatan inflamasi. Sumber: Bente D, et al, $2009 .^{6}$

\section{Penanganan}

Penanganan infeksi virus Ebola hanya bersifat suportif untuk mempertahankan fungsi jantung dan ginjal, menyeimbangkan elektrolit, dan mencegah komplikasi penyerta. Umumnya penderita mengalami dehidrasi sehingga dibutuhkan penggantian cairan dan faktor koagulasi yang berguna untuk menghentikan perdarahan serta memperbaiki oksigenasi. ${ }^{5}$ Rehidrasi oral dapat direkomendasikan tetapi kadang tidak realistis karena adanya nyeri tenggorokan, muntah, dan lemah badan yang berkepanjangan. Tujuan utama penanganan ialah untuk menyiapkan layanan kesehatan yang optimal pada penderita dengan proteksi maksimal. ${ }^{3}$

Pada tahap awal infeksi virus Ebola dapat tidak terlalu berjangkit. Kontak dengan seseorang yang sedang terjangkit virus ini pada tahap awal tidak terlalu berjangkit, tetapi seiring dengan perjalanan penyakit, kontak dengan cairan tubuh 
misalnya dari diare, muntah, atau perdarahan dapat berakibat fatal. ${ }^{7}$

\section{Mortalitas}

Mortalitas penderita infeksi virus Ebola ini masih tinggi pada manusia dengan angka kematian 50-89\%, tergantung dari jenis spesies virus. Penyebab kematian biasanya disebabkan oleh syok hipovolemik atau gagal organ. ${ }^{6}$

\section{Pencegahan}

Pencegahan terhadap infeksi virus Ebola mencakup beberapa hal:

1. Isolasi pasien infeksi Ebola dari pasien lainnya

2. Mengurangi penyebaran penyakit dari kera dan babi yang terinfeksi ke manusia. Hal ini dapat dilakukan dengan memeriksa hewan tersebut terhadap kemungkinan infeksi, serta membunuh dan membakar hewan dengan benar jika ditemukan menderita penyakit tersebut. Memasak daging dengan benar dan mengenakan pakaian pelindung ketika mengolah daging juga mungkin berguna, begitu juga dengan mengenakan pakaian pelindung dan mencuci tangan ketika berada di sekitar orang yang menderita penyakit tersebut. Sampel cairan dan jaringan tubuh dari penderita penyakit harus ditangani dengan sangat hati-hati.

3. Menggunakan sarung tangan dan perlengkapan pelindung diri yang lengkap, dalam hal ini standard precautions (termasuk mencuci tangan sebelum dan sesudah memeriksa pasien)
4. Persiapan pembakaran dengan benar jenazah individu yang meninggal karena virus Ebola untuk mencegah penularan

\section{SIMPULAN}

Infeksi virus Ebola merupakan penyakit sangat menular dengan angka kematian yang tinggi; oleh karena itu pencegahan yang baik sangat dibutuhkan untuk menekan penularannya.

\section{DAFTAR PUSTAKA}

1. Baize S, Pannetier D, Oestereich L, Rieger T, Koivogui L, Magassouba N, et al. Emergence of Zaire ebola virus disease in Guinea - Preliminary report. N Eng J Med. 2014:1-8.

2. Sullivan N, Yang YZ, Nabel GJ. Ebola virus pathogenesis: implications for vaccines and therapies. $\mathrm{J}$ Virol. 2003;77(18):9733-7.

3. Muyumbe-Tamfum JJ, Mulangu $\mathrm{S}$, Masumu J, Kayambe JM, Kemp A, Paweska J. Ebola virus outbreaks in Africa: Past and present. Onderstepoort Journal of Veterinary Research. 2012;79(2).

4. Leroy EM, Rouquet P, Formenty P, Souquiere S. Multiple Ebola virus transmission events and rapid decline of central African wildlife. Science. 2004;303:387-90.

5. Tyagi S, Kumara S, Singla M. Clinical aspects of Ebola hemorrhagic fever: a review. International Journal of Pharma and Bio Sciences. 2010;1:1-9.

6. Bente D, Gren J, Strong J, Feldmann H. Disease modeling for Ebola and Marburg virus. DMM. 2009;2:12-7. 